\title{
Principal Figures
}

From East Asia

Chinggis Khan (r. 1206-1227), founder of the Mongol Empire, conqueror of Central Asia, the Tangut Empire in Northwest China and part of the territory of the Chin Dynasty of North China.

Güyüg Khan (r. 1246-1248), Great Khan of the Mongols, Chinggis's grandson and Khubilai's cousin.

Khubilai Khan (r. 1260-1294), Great Khan of the Mongols, founder of the Yüan dynasty of China, Chinggis's grandson.

Markos (Mar Yaballaha) (1245-1317), Nestorian monk, traveling companion of Rabban Sauma and Patriarch of the Nestorian Church (1281-1317).

Möngke Khan (r. 1251-1259), Great Khan of the Mongols, Khubilai's brother.

Ögödei Khan (r. 1229-1241), Great Khan of the Mongols at the time of their conquest of much of Russia and their final destruction of the Chin Dynasty of North China, Chinggis's son.

Rabban Sauma (Bar Sauma) (ca. 1225-1294), Nestorian monk, first voyager from China to the West. 


\section{From Central Asia and the Middle East}

Abakha Khan (r. 1265-1282), Mongol Ilkhan of Persia at the time of Rabban Sauma's arrival in the Middle East.

Andronicus II (r. 1282-1328), Byzantine Emperor at the time of Rabban Sauma's arrival in Constantinople.

Aḥmad (Tegüder Khan) (r. 1282-1284), Mongol Ilkhan of Persia, convert to Islam.

Arghun Khan (r. 1284-1291), Mongol Ilkhan of Persia, who chose Sauma as ambassador to Western Europe.

Berke Khan (r. 1257-1267), Mongol ruler of the Golden Horde of Russia, convert to Islam, Chinggis's grandson.

Geikhatu Khan (r. 1292-1295), Mongol Ilkhan of Persia, Arghun's brother.

Ghazan Khan (r. 1295-1304), Mongol Ilkhan of Persia, convert to Islam, Arghun's son.

Hülegü Khan (r. 1258-1265), founder of the Ilkhanate of Persia, Khubilai's brother.

Mar Denha (d. 1281), Patriarch of the Nestorian Church.

Michael VIII (Michael Palaeologus) (r. 1261-1282), Byzantine Emperor who recaptured Constantinople from the Venetians, supporter of union with the Catholic Church.

\section{From Europe}

Charles of Anjou (r. 1266-1285), King of Naples and Sicily at the time of the Sicilian Vespers revolt (1282), St. Louis's brother.

Edward I (r. 1272-1307), King of England who met Rabban Sauma in Bordeaux.

Innocent IV (Pope, 1243-1254), Pope who convened the Ecumenical Council in Lyons (1245).

John of Plano Carpini, Papal emissary to the Mongols, 1245-1247.

Julian, Dominican ambassador to the Mongols, 1236. 
Louis IX (St. Louis) (r. 1226-1270), King of France, leader of Crusades (1248-1250 and 1270).

Nicholas IV (Jerome of Ascoli) (Pope, 1288-1292), Pope at the time of Rabban Sauma's second visit to Rome.

Philip III (Philip the Bold) (r. 1270-1285), King of France who added territory to the nation, son of Saint Louis.

Philip IV (Philip the Fair) (r. 1285-1314), King of France at the time of Rabban Sauma's arrival in Paris, grandson of St. Louis.

William of Rubruck, Emissary to the Mongols, 1253-1255. 

Voyager from
Xanadu 
